\title{
APPLICATION OF NUMERICAL MODELING IN QUANTITATIVE ASSESSMENT OF BHT DISPERSION IN PE-HD PIPES
}

\author{
ZASTOSOWANIE MODELOWANIA NUMERYCZNEGO W ILOŚCIOWEJ \\ OCENIE TRANSPORTU BHT W PRZEWODACH PE-HD
}

\begin{abstract}
PE-HD water pipes are exposed to adverse environmental conditions, both during production and their subsequent use in the civil engineering. Several organic compounds migrating into water may lead to deterioration of water quality, especially its taste and odour. Commonly used antioxidant BHT and its products of degradation are leached into water as a result of degradation of the PE-HD pipes material. This paper presents the results of laboratory tests of BHT concentration changes in water circulating in the PE-HD close loop pipe of $30 \mathrm{~m}$ length as well as of numerical studies based on data obtained by the laboratory measurements. Numerical calculations were performed using the commercial software Fluent, Ansys Inc., based on the computational fluid dynamics (CFD) principles. The analysis of water samples confirmed the migration of the antioxidant from the pipe material into the water. The results of numerical analysis gave good agreement with the measured values.
\end{abstract}

Keywords: antioxidants migration, BHT, PE-HD pipes, numerical modeling

\section{Introduction}

High density polyethylene (PE-HD) is now the material more and more often used for the construction of new and renovation of old networks and water supply systems [1]. Water pipes made of PE-HD are exposed to adverse environmental conditions, both at the production and their later use in construction. Polyethylene pipes exposure to UV radiation, high temperature, mechanical stress, oxidative compounds used for water disinfection can lead to damage and degradation of pipes' material and release of organic compounds form the material of water pipes [2-4]. Effect of external factors on the polymer can lead to breakage of polymer chain and the simultaneous formation of two free radicals. These free radicals usually react with oxygen forming peroxides, which in turn, react with hydrogen atom from the second polymer chain. One external factor may thus lead to a chain reaction of radical formation and polymer degradation.

In order to improve mechanical and physical properties and to extend the life of pipes made of PE-HD to the material at the stage of production, organic and inorganic compounds

\footnotetext{
${ }^{1}$ Faculty of Environmental Engineering, Lublin University of Technology, ul. Nadbystrzycka 40B, 20-618 Lublin, Poland, phone +48 815384138

*Corresponding author: email: a.musz@wis.pol.lublin.pl
} 
such as: stabilizers or fillers are added [4-11]. Stabilizers are substances designed to improve polymer resistance to aging in time of its processing as well as during the use of material. Among stabilizers the following can be distinguished: thermal stabilizer, light stabilizer, antioxidants and biological stabilizers [12]. Due to radical character of degradation process, polyethylene is inhibited by antioxidants - phenol derivatives, aminophenol and amines. Antioxidants are used in the production of almost all commercial polymers in an amount of up to $2 \%$ [13]. Antioxidants used in the process of polyethylene production can be divided into two types: primary, which are incorporated in the polymer chain, and secondary [14-15]. Primary stabilizers prevent or interrupt oxidation reaction, while secondary ones prevent the formation of free radicals by disintegration of unstable hydroperoxides before their automatic hemolytic decomposition [16]. Substances and products of their degradation introduced into the polymer can migrate from the pipes' material to water which is in contact with them.

Denberg et al [17] grouped compounds released from the polyethylene pipes into water in the three following groups: (1) antioxidants (2) products of antioxidants degradation (3) PE broken chains having functional, polar oxygen group. Research results presented in numerous studies show that organic compounds migrating into water can cause changes in its organoleptic properties, eg deterioration of taste and smell [6, 8, 17-21]. Compounds responsible for the deterioration of the organoleptic properties of water include BHT antioxidant (4-methyl-2,6-di-tert-butyphenol), or products of its degradation, alkylobenzenes, ketones or esters [22]. Research carried out among others by Mikami et al [23], Matsuo et al [24], Fernandez-Alvarez et al [25] shown that BHT released into the water is degraded as a result of oxidation reaction and forms the following compounds: BHT-COOH (3,5-di-tert-butyl-4-hydroxybenzoic acid), BHT-OH (2,6-di-tert-butyl-4(hydroxymethyl)phenol), BHT-CHO (3,5-di-tert-butyl-4-hydroxybenzaldehyde), BHT-Q (2,6-di-tert-butylcyclohexa-2,5-diene-1,4-dione).

BHT is a fat-soluble antioxidant that has found wide application in industry: polymer, fuel, food and pharmaceutical [26]. The melting point of BHT is about $70^{\circ} \mathrm{C}$, solubility in the water $0.611 \mathrm{~g} / \mathrm{m}^{3}$ (at $20-25^{\circ} \mathrm{C}$ ), and its density $1.03 \mathrm{~g} / \mathrm{cm}^{3}$. According to Directive $67 / 548 / \mathrm{EWG}$ on the classification of dangerous chemicals, BHT is flammable, toxic and irritant compound. This compound is considered as safe to use if the amount of the antioxidant in food does not exceed $0.02 \%$ of the total fats and oils [26]. BHT is also used to improve the stability of pharmaceuticals, fat-soluble vitamins and cosmetics [27]. Addition of BHT to plastics prevents polymer decomposition during its processing, and extends life of the finished products [28]. For example, the addition of BHT to polyolefins,

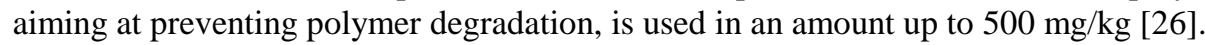

Modeling of water quality in distribution networks is now becoming a very useful tool supporting designing process and network management. Water quality models allow for the prediction of threats and research on negative changes occurring in water during its transport on the way from water supply station to the consumer. In the previously used models of water quality, particular attention was paid to the chlorine transport modeling as the primary indicator of quality and popular water disinfectant [29-31]. Computational Fluid Dynamics methods (CFD) allow to calculate dispersion of contaminants in water pipes at different flow conditions, having regard to chemical reactions in water and on the walls of pipes [17, 32-34]. CFD is now being used with great success in many areas of science and technology, including the modeling of hydraulic parameters in water supply systems, as well 
as in the sewer systems [35-39]. One of the most popular commercial CFD software with wide range of computing capabilities is Fluent, Ansys Inc. [40-44]. Fluent is a comprehensive tool for the numerical analyses of single- and multi-phase phenomena in connection with heat and mass exchange, as well as with chemical reactions. The literature contains many examples of use of Fluent software in a variety of fluid flow simulation calculations [43-46].

Mathematical description of water movement in water pipes applied in Fluent model is based on the laws of conservation of mass, momentum, and the Navier-Stokes equation. Above mentioned equations are solved on the basis of the parameterization made in a given center, entered initial data and defined boundary conditions [43, 47-49]. Qualitative calculations including transport, mixing and disintegration of chemical compounds in the water reacting or not with other components of the mixture, are usually based on the equation of mass conservation for a given component of the mixture [50]:

$$
\frac{\rho}{\partial t}\left(\rho Y_{i}\right)+\nabla\left(\rho \vec{u} Y_{i}\right)=-\nabla \vec{J}_{i}+R_{i}+S_{i}
$$

where: $Y_{i}$ - local mass fraction of contaminant $i, \vec{J}_{i}$ - vector of diffusive contaminant flow $i$, $R_{i}$ - source element of contaminant increase $i$ as a result of chemical reactions, $S_{i}$ - source element of contaminant increase $i$ as a result of the inflow from the source (pipe material).

The aim of this article is presented the laboratory tests of BHT concentration changes in water circulating in the loop with a length of $30 \mathrm{~m}$, made of new PE-HD pipes, and numerical investigations. Numerical calculations were performed using commercial software Fluent, Ansys Inc. basing on the computational fluid dynamics (CFD). Numerical calculations were used for quantitative evaluation of the analyzed antioxidant in the water having contact with the PE-HD pipes.

\section{Materials and methods}

\section{Measuring installation}

Laboratory measurements of changes in the concentration of BHT in the water were carried out on a specially prepared laboratory stand (Fig. 1). It was built with new PE-HD 80 pipes, PN 12.5, with a diameter of $32 \times 3.0 \mathrm{~mm}$ produced in Poland in accordance with PN-EN 12201-2:2011 purchased straight from the manufacturer. Pipeline length was $30 \mathrm{~m}$, inner surface of pipes $2.45 \mathrm{~m}^{2}$, and the volume of water in the analyzed system $-15.9 \mathrm{~m}^{3}$. Basic parameters of the pipe were as follows: density $954 \mathrm{~g} / \mathrm{m}^{3}$, impact strength according to Charpy $-6 \mathrm{~kJ} / \mathrm{m}^{2}$, tensile strength at $20^{\circ} \mathrm{C}-33 \mathrm{MPa}$, melt flow rate MFR (190/5) 0.2-1.3 g/10 min.

Before testing, laboratory stand was rinsed with deionized water prepared with Milli-Q (Millipore, Molsheim, Germany) providing at least 3-fold change of water in the system. Then, laboratory stand was filed with test water. Basic parameters of deionized water used for rinsing and then for filling the system were as follows: TOC $\leq 0.5 \mathrm{ppb}$, resistivity $18.2 \mathrm{M} \Omega \mathrm{m}$, conductivity $0.055 \mu \mathrm{S} / \mathrm{cm}$, and $\mathrm{pH}=5.95$. The water flow velocity in the system equal $0.6 \mathrm{~m} / \mathrm{s}(\operatorname{Re}=13650)$ was maintained with the help of WILO MVIe 203-1/16/E/3-2/B centrifugal pump. Water samples were collected into testing glass vials with a capacity of $40 \mathrm{~cm}^{3}$ in accordance with the schedule of research, and then they were 
subjected to the analysis by gas chromatography Trace Ultra Thermo coupled with Polaris $\mathrm{Q}$ (GC-MS) mass spectrometer. The time schedule of water sampling is shown in Table 1.

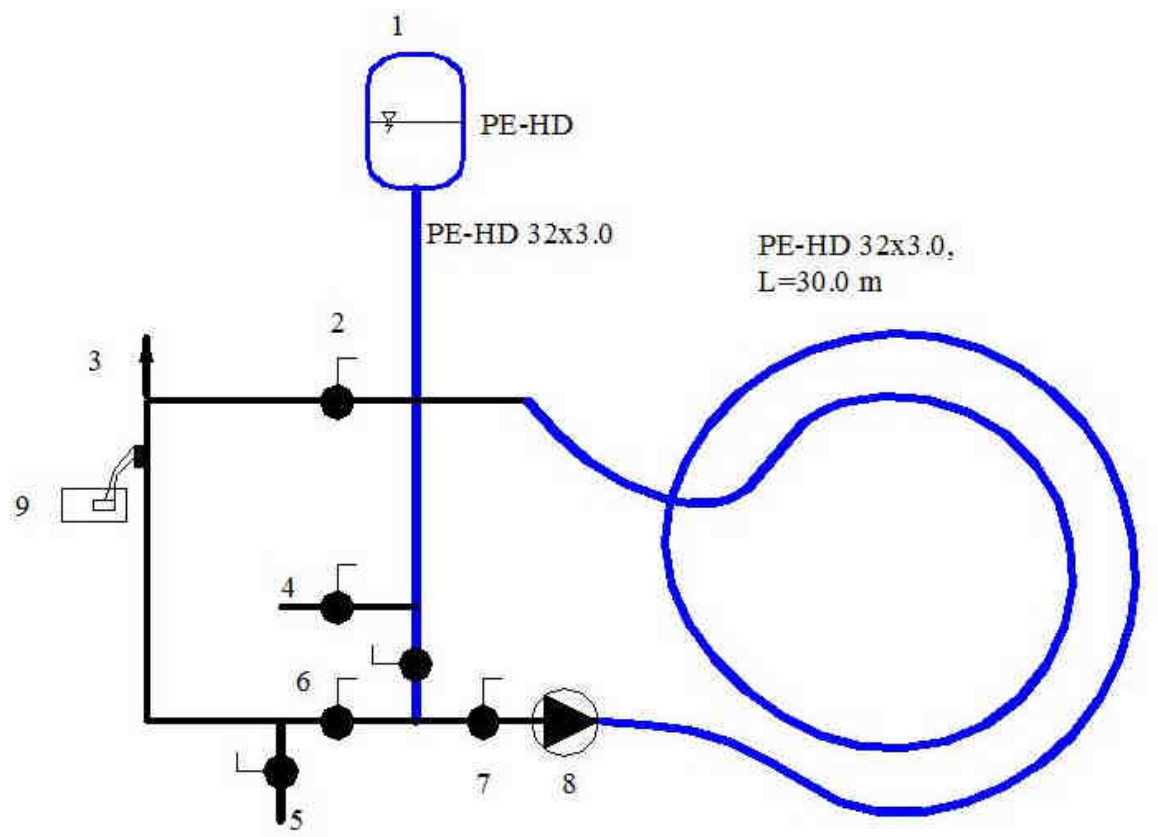

Fig. 1. Scheme of the laboratory stand: 1 - water tank to fill up installation, 2 - analyzed pipe, 3 - vent valve, 4 - drain valve, 9 - PortaFlow 300 ultrasonic flowmeter, 6, 7, 5, 10 - stop valve, 8 - centrifugal pump

Schedule and samples marking

\begin{tabular}{|c|c|c|c|c|c|c|c|c|c|c|}
\hline Sample marking & A & B & C & D & E & F & G & H & I & J \\
\hline Hour $[\mathrm{h}]$ & 0 & 2 & 4 & 6 & 11 & 24 & 48 & 72 & 100 & 147 \\
\hline
\end{tabular}

Prepared samples were subjected to stationary phase extraction using a blue SPME fiber (stationary phase film thickness $65 \mu \mathrm{m}$, type of stationary phase: polydivinylsiloxan/divinylbenzene - PDMS/DVB), for a period of $40 \mathrm{~min}$ by Head Space method at $25^{\circ} \mathrm{C}$. Then, the sample was dosed directly from the fiber on the fiber dispenser of gas chromatography, and for 10 minutes at $270^{\circ} \mathrm{C}$ desorption was carried out in 'splitless' option using appropriate temperature program of the column in order to achieve desorption from the fiber. Gas chromatography working conditions were as follows: analytical column RTx5 (Dioxin) $60 \mathrm{~m} \times 0.25 \mathrm{~mm} \mathrm{df}=0.15 \mu \mathrm{m}$ by Restek, as a carrier gas was used He $(99.9996 \%)$ flowing with intensity of $1.2 \mathrm{~cm}^{3} / \mathrm{min}$. Working conditions of Polaris Q-Thermo mass detector were as follows: ion source temperature $-250^{\circ} \mathrm{C}$, transfer line temperature $-275^{\circ} \mathrm{C}$. Results of the analysis were retention spectra (area under peak of characteristic ion - base peak - 205) and mass spectra confirming the presence of the analyzed compound. 


\section{Results of laboratory measurements}

Results of laboratory measurements of water samples, carried on GC-MS are shown in Table 2.

Detectability limit for water samples marked by GC-MS was $2.7 \mu \mathrm{g} / \mathrm{dm}^{3}$, while quantification limit (QL) was $8.1 \mu \mathrm{g} / \mathrm{dm}^{3}$.

BHT concentration in the water from the measuring stand

\begin{tabular}{|c|c|c|c|c|c|c|c|c|c|c|}
\hline Sample No & A & B & C & D & E & F & G & H & I & J \\
\hline Hour $[\mathrm{h}]$ & 0 & 2 & 4 & 6 & 11 & 24 & 48 & 72 & 100 & 147 \\
\hline $\begin{array}{c}\text { BHT concentration } \\
{\left[\mu \mathrm{g} / \mathrm{dm}^{3}\right]}\end{array}$ & 20.8 & 19.8 & 41.1 & 49.5 & 60.9 & 93.9 & 115.3 & 138.4 & 177.6 & 194.2 \\
\hline $\begin{array}{c}\text { Water temperature } \\
{\left[{ }^{\circ} \mathrm{C}\right]}\end{array}$ & 21.6 & 22.2 & 22.4 & 22.9 & 23.5 & 22.3 & 22.5 & 23.0 & 24.1 & 25.0 \\
\hline
\end{tabular}

For the first 40 hours of measurements (samples from A to $\mathrm{G}$, samples marking in accordance with Table 2), counting from the start of the measurements, the fastest BHT growth in the water was observed.

Revealed results of measurements of the BHT concentration in the water indicate that after about 70 hours, counting from the start of the measurements, in the samples relatively small increase of antioxidant content was observed. During the duration of measurement, 10-fold concentration increase was observed, from $20.8 \mu \mathrm{g} / \mathrm{dm}^{3}$ (in the first hour of measurement, $t=0$ ) to $194.2 \mu \mathrm{g} / \mathrm{dm}^{3}$ (in the last hour of measurement $t=147 \mathrm{~h}$ ). Obtained results of BHT concentration in the water are comparable with the values obtained by via Widomski et al $[46,51]$ for BHT migrating from PE-HD 100 pipes.

Measuring system construction and the realization of research on BHT concentration changes in water flowing through the installation, enabled object parameterization - defining physical quantities (length, pipe's diameter, material data, etc.) necessary to perform a computer simulation of BHT propagation.

\section{Modelling study}

A fragment of the finite element mesh of model including the control volume and the area that reflects water volume in the pipe is shown in Figure 2.

Our modelling attempt contains several simplifications. Changes of BHT concentration caused by water sampling for chemical analyses, and the addition of ultrapure water in order to make up the capacity of measuring stand was not included in the calculation, due to its negligible values. The model does not take into account the chemical reaction of antioxidant degradation in the water. Our model does not reflect the oxidation reaction of BHT in water either.

Time duration of our simulation covered 147 hours of constant flow inside the closed-loop pipe with mean flow velocity of $0.6 \mathrm{~m} / \mathrm{s}$. The standard, two-equations, $k-\varepsilon$ turbulence model with standard wall functions was applied to our modelling calculations of viscous, incompressible liquid flow. Currently, the $k-\varepsilon$ model is one of the most popular models presenting the flow turbulence of an incompressible fluid at low speeds [52]. Reynolds' turbulent stress tensor in this model is described by additional equation [53]: 


$$
\tau_{i j}=\mu_{t}\left(\bar{u}_{i j}+\bar{u}_{j i}\right)-\frac{2}{3} \bar{\rho} k \delta_{i j}, \mu_{t}=\rho c_{\mu} \frac{k^{2}}{\varepsilon}
$$

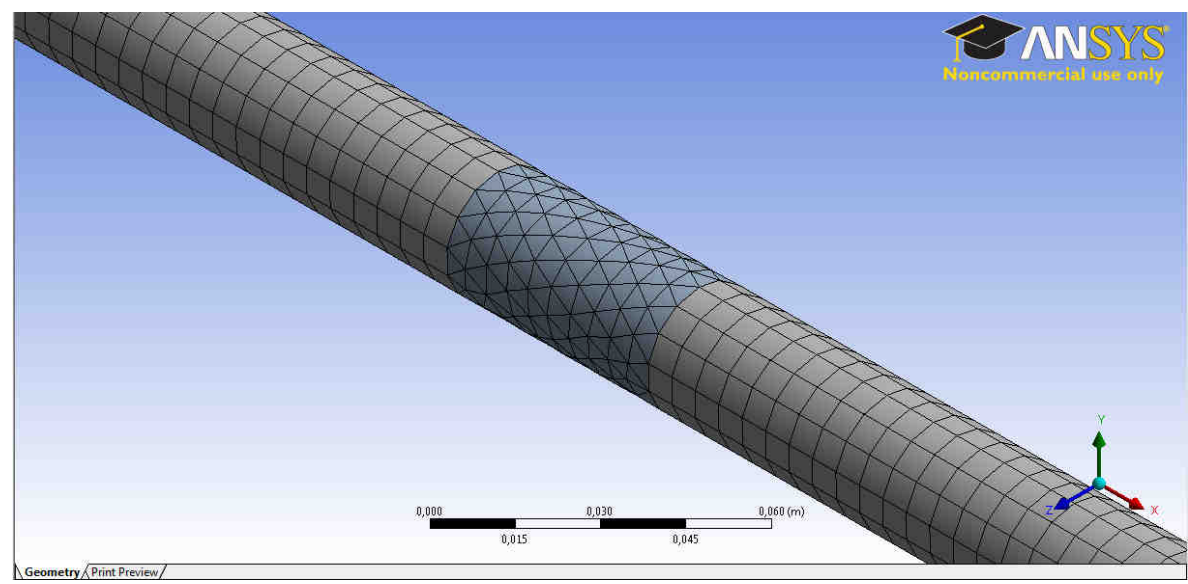

Fig. 2. Fragment of the developed finite element mesh

Solution of the $k-\varepsilon$ model requires the introduction of two equations of transport describing additional variables of equation (2) [54]:

- $\quad$ kinetic energy of turbulence $k$ :

$$
\frac{\partial}{\partial t}(\bar{\rho} k)+\left(\bar{\rho} k \bar{u}_{i}\right)_{, i}=\left(\bar{\tau}_{i j} \bar{u}_{j}\right)_{, i}-\bar{\rho} \varepsilon+\left(\mu_{k} k_{, i}\right)_{, i}
$$

- dissipation of turbulence kinetic energy $\varepsilon$ :

$$
\frac{\partial}{\partial t}(\bar{\rho} \varepsilon)+\left(\bar{\rho} \varepsilon \bar{u}_{i}\right)_{, i}=c_{\varepsilon 1}\left(\bar{\tau}_{i j} \bar{u}_{j}\right)_{, i}-\frac{c_{\varepsilon 2} \bar{\rho} \varepsilon^{2}}{k}+\left(\mu_{\varepsilon} \varepsilon_{, i}\right)_{, i}
$$

where: $\mu_{t}$ - turbulent viscosity coefficient $[\mathrm{kg} /(\mathrm{m} \cdot \mathrm{s})], \tau_{i j}$ - turbulent stress vector [Pa], $\rho$ - density of fluid $\left[\mathrm{kg} \cdot \mathrm{m}^{-3}\right], \sigma$ - standard deviation $[-]$,

$$
\mu_{k}=\mu+\frac{\mu_{t}}{\sigma_{k}}, \mu_{\varepsilon}=\mu+\frac{\mu_{t}}{\sigma_{\varepsilon}}, c_{\mu}, c_{\varepsilon 1}, c_{\varepsilon 2} \text { - model constants. }
$$

The value of pipe wall roughness equal to $1 \cdot 10^{-5} \mathrm{~m}$ was applied. Simulations were performed for water of temperature $23^{\circ} \mathrm{C}$, density $994.25 \mathrm{~kg} / \mathrm{m}^{3}$, dynamic viscosity $7.2974 \cdot 10^{-4} \mathrm{~kg} /(\mathrm{m} \cdot \mathrm{s})$ and specific heat equal to $4069.1 \mathrm{~J} /(\mathrm{kg} \cdot \mathrm{K})$. The molecular mass of BHT applied in modelling was equal to $220.35 \mathrm{~g} / \mathrm{mol}$, while assumed value of diffusion coefficient for BHT in water, according to our own measurements and calculations, was equal to $7.15 \cdot 10^{-16} \mathrm{~m}^{2} / \mathrm{s}[51,55]$. For the start time of installation filling $t=0$ and $c_{B H T}=0 \mu \mathrm{g} / \mathrm{dm}^{3}$. The initial condition of BHT concentration was described as pollutant mass fraction in $\mathrm{t}=$ the end of filling the installation equal to $2.08 \cdot 10^{-8}$ (concentration $c_{B H T}=20.8 \mu \mathrm{g} / \mathrm{dm}^{3}$ ). The required boundary condition for BHT mass transport on the limit of water body (border between water body and pipe material) was assumed as first type, time varying Dirichlet condition described as a specific BHT mass fraction. The value of 
BHT mass fraction applied as the boundary condition, reflecting the concentration of BHT migrating from plastic pipe to a thin layer covering pipe wall was determined by a trial and error method [56, 57]. Calculations were performed for the constant length of time step equal to $60 \mathrm{~s}$. Results of our calculations covered spatial, 3D distributions of, inter alia, flow velocity magnitude, axial and radial velocity, turbulence energy and intensity as well as BHT mass fraction. Input data assumed for the calculation is presented in Table 3.

Input data to simulation calculations

\begin{tabular}{|c|c|c|c|c|c|c|}
\hline $\begin{array}{c}\text { Average } \\
\text { flow velocity }\end{array}$ & $\begin{array}{c}\text { Water } \\
\text { temperature }\end{array}$ & $\begin{array}{c}\text { Water } \\
\text { viscosity } \\
\text { coefficient }\end{array}$ & $\begin{array}{c}\text { BHT } \\
\text { molar } \\
\text { mass }\end{array}$ & $\begin{array}{c}\text { Coefficient of BHT } \\
\text { diffusion from the } \\
\text { material to water }\end{array}$ & $\begin{array}{c}\text { Boundary } \\
\text { condition } \\
\text { Dirichlet, } \\
\text { mass fraction }\end{array}$ & Time \\
\hline$[\mathrm{m} / \mathrm{s}]$ & {$[\mathrm{K}]$} & {$[\mathrm{Pa} \cdot \mathrm{s}]$} & {$[\mathrm{g} / \mathrm{mol}]$} & {$\left[\mathrm{m}^{2} / \mathrm{s}\right]$} & {$[-]$} & {$[\mathrm{h}]$} \\
\hline 0.60 & 288 & 0.001308 & 220.35 & $7.15 \cdot 10^{-16}$ & $9.15 \cdot 10^{-7}$ & $t=0-t=24$ \\
\cline { 5 - 7 } & & & & & $2.37 \cdot 10^{-7}$ & $t=25-t=147$ \\
\hline
\end{tabular}

\section{Results and discussion}

Calculation results of BHT transport in water included three-dimensional division of mass fraction of the analyzed antioxidant. The results of simulation computations of BHT concentration changes for each hour are shown in Table 4.

Table 4

Results of numerical calculations of BHT concentration changes in the water

\begin{tabular}{|c|c|c|c|c|c|c|c|c|c|c|c|}
\hline Time & {$[\mathrm{h}]$} & 0 & 2 & 4 & 6 & 11 & 24 & 48 & 72 & 100 & 147 \\
\hline $\begin{array}{c}\text { BHT } \\
\text { concentration }\end{array}$ & {$\left[\mu \mathrm{g} / \mathrm{dm}^{3}\right]$} & 0 & 71.5 & 76.6 & 77.7 & 79.1 & 82.2 & 109.0 & 134.0 & 156.9 & 184.7 \\
\hline
\end{tabular}

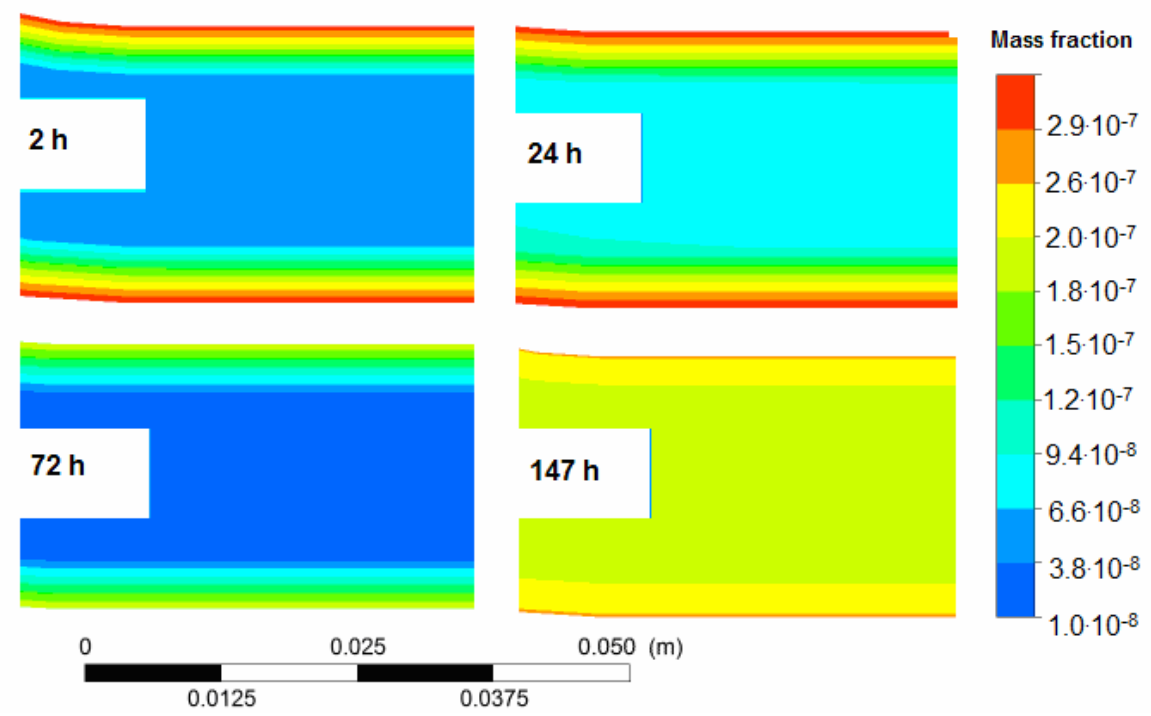

Fig. 3. BHT mass fraction distribution in selected cross-section of pipe for flow rate $v=0.6 \mathrm{~m} / \mathrm{s}$ in $2^{\text {nd }}$, $24^{\text {th }}, 72^{\text {nd }}$ and $147^{\text {th }}$ hour (boundary condition: $t=0-24 \mathrm{~h}-9.15 \cdot 10^{-7}, t=25-147 \mathrm{~h}-2.37 \cdot 10^{-7}$ ) 
Figure 3 shows change of the BHT mass fraction distribution in selected sections of the pipe.

BHT mass fraction division in the water for the flow rate $v=0.60 \mathrm{~m} / \mathrm{s}$ indicates that during the following hours of the research it increases. During the simulation calculations, the increase of mass fraction value has been observed from $7.15 \cdot 10^{-8}$ (in the $2^{\text {nd }}$ hour) to $1.85 \cdot 10^{-7}$, which corresponds to the following concentrations: from $c=71.5 \mu \mathrm{g} / \mathrm{dm}^{3}$ to $c=185.0 \mu \mathrm{g} / \mathrm{dm}^{3}$. The observed calculated BHT mass fraction distribution in the water stream reveals that for a given water flow rate, complete BHT mixing in the water was not observed in any hour of measurements.

Figure 4 shows BHT concentration changes in time obtained for the measured and calculated values.

BHT content increase in the water, observed during numerical calculations, is consistent with the measured values. In both cases, more than 9-fold increase of BHT in the water has been observed.

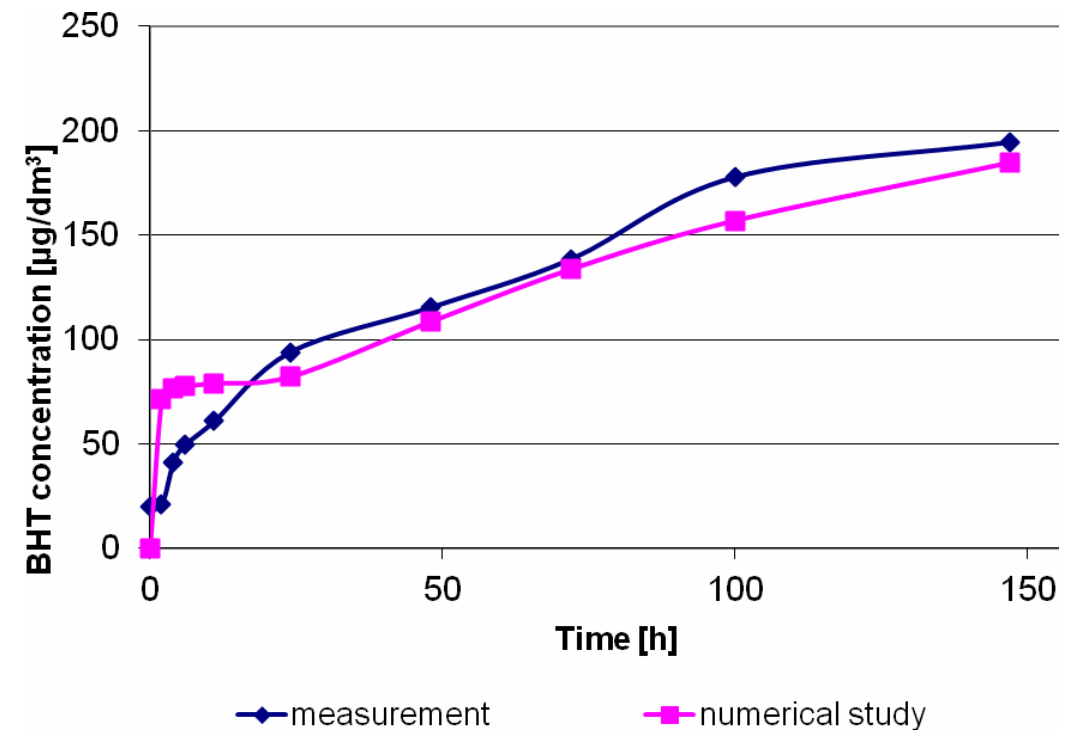

Fig. 4. BHT concentration change in time obtained for the measured and calculated values

Average values of BHT concentration in the water obtained by numerical calculations, show quite good agreement with measured values. Correlation coefficient $R=0.92$ and determination coefficient $R^{2}=0.83$ were determined at a given confidence level of $95 \%$.

In addition, the prognostic value of the constructed model was evaluated by mean square error, RMSE (Root Mean Square Error) and Nash-Sutcliff's effective coefficient of the model $(E)$. RMSE $=0.02 \mu \mathrm{g} / \mathrm{dm}^{3}$ (for measured values from 20.8 to $194.2 \mu \mathrm{g} / \mathrm{dm}^{3}$ ) obtained for numerical model of contaminants transport in the water provides high prognostic capability of the constructed numerical model.

Calculated Nash-Sutcliff's coefficient $E=0.76$ also shows high efficiency of the numerical model. 


\section{Conclusions}

Conducted laboratory measurements and numerical calculations show an increase of BHT concentration in the water volume filling the closed loop PE-HD pipe. During laboratory research, in $147^{\text {th }}$ hour, counting form the start of the measurements, almost 10-fold increase of BHT in the water (from $c=19.8 \mu \mathrm{g} / \mathrm{dm}^{3}$ to $c_{147}=194.2 \mu \mathrm{g} / \mathrm{dm}^{3}$ ) was observed. Calculated values were changing form $c_{2}=71.5 \mu \mathrm{g} / \mathrm{dm}^{3}$ to $c_{147}=185.0 \mu \mathrm{g} / \mathrm{dm}^{3}$. Numerical calculations of BHT propagation in water conducted by finite elements method allow for obtaining the results characterized by considerable compliance with the values of laboratory measurements. The calculated final BHT content was lower that the measured value by $4.7 \%$. Values of the coefficients of: correlation $R=0.92$ and determination $R^{2}=0.83$ confirmed that a very good agreement with compared sets was achieved. Calculated values of mean square error RMSE $=0.02 \mu \mathrm{g} / \mathrm{dm}^{3}$ and Nash-Sutcliff's coefficient $E=0.76$ reveal high prognostic ability and efficiency of the model. However, to obtain such a good agreement of the results, two values of boundary condition for contaminants transport were necessary to introduce $\left(t=0-24 \mathrm{~h}-9.15 \cdot 10^{-7}, t=25-147 \mathrm{~h}\right.$ $2.37 \cdot 10^{-7}$ ). The reason of this may be omitting the chemical reaction of BHT decomposition in water with oxygen in the numerical model. Our laboratory measurements and numerical calculations shown the necessity for further research with regard to chemical models of the analyzed contaminant mass transport, as well as examine and describe the kinetics of the reaction of BHT decomposition in the flowing water and including received results into the developed numerical model.

\section{Acknowledgements}

This paper was supported by the research project of the Polish Ministry of Science and Higher Education No UMO 2011/01/N/ST8/635.

\section{References}

[1] Kwietniewski M. Rurociągi polietylenowe w wodociągach i kanalizacji - rozwój rynku w Polsce i niezawodność funkcjonowania. Gaz, Woda i Technika Sanitarna. 2004;3:78-82.

[2] Castagnetti D, Mammano GS, Dragoni E. Polym Test. 2011;30:277-285. DOI: 10.1016/j.polymertesting.2010.12.001

[3] Hassinen J, Lundback M, Ifwarson M, Gedde UW. Polym Degrad Stabil. 2004;84:261-267. DOI: 10.1016/j.polymdegradstab.2011.02.009.

[4] Thörnblom K, Palmlöf M, Hjertberg T. Polym Degrad Stabil. 2011;96(10):1751-1760. DOI: 10.1016/j.polymdegradstab.2011.07.023.

[5] Haider N, Karlsson SJ. Appl Polym Sci. 2002;85:974-988. DOI: 10.1002/app.10432.

[6] Brocca D, Arvin E, Mosback H. Water Res. 2002;36:3675-3680. DOI: 10.1016/S0043-1354(02)00084-2.

[7] Marcato B, Guerr AS, Vianello M, Scalia S. Int J Pharmaceut. 2003;257:217-225. DOI: 10.1016/S0378-5173(03)00143-1.

[8] Tomboulian P, Schweitzer L, Mullin K, Wilson J, Khiari D. Materials used in drinking water distribution systems: contribution to taste-and-odor. Water Sci Technol. 2004;49:219-226.

[9] Gather R, Muller H. Plastic additives in polyolefin additive analysis. J Liq Chromatogr. 1993;16:1625- 1638 .

[10] Marcato B, Vianello M. J Chromatogr A. 2000;869:285-300. DOI: 10.1016/S0021-9673(99)00940-1.

[11] Farmer R, Pike R, Cheng G. Comput Chem Eng. 2005;29: 2386-2403. DOI: 10.1016/j.compchemeng.2005.05.022.

[12] Łużny W. Wstęp do nauki o polimerach. Kraków: Uczelniane Wydawnictwa Naukowo-Techniczne AGH; 1999. 
[13] Ritter A, Michel E, Schmid M, Affolter S. Pol Test. 2005;24:498-506. DOI: 10.1016/j.polymertesting.2004.11.012.

[14] Pospíšil J. Chemical and photochemical behaviour of phenolic antioxidants in polymer stabilization - a state of the art report, Part I. Polym Degrad Stabil. 1993;40(2):217-232.

[15] Vulic I, Vitarelli G, Zenner JM. Polym Degrad Stabil. 2002;78:27-34. DOI: 10.1016/S0141-3910(02)00115-5.

[16] Pinto AM. Quantitative Analysis of Antioxidants from High Density Polyethylene (HDPE) by off-line Supercritical Fluid Extraction Coupled High Performance Liquid Chromatography. Blacksburg, Virginia: Master of Science in Chemistry; 1997.

[17] Denberg M, Arvin E, Hassager O. J Water Supply: Res T - AQUA. 2007;56:435-443. DOI: 10.2166/aqua.2007.020.

[18] Koch A. Gas Chromatographic Methods for Detecting the Release of Organic Compounds from Polymeric Materials in Contact with Drinking Water. Gelsenkirchen, Germany: Hygiene-Institut des Ruhrgebiets; 2004.

[19] Schweitzer L, Tomboulian P, Atasi K, Chen T, Khiari D. Utility quick test for analyzing materials for drinking water distribution systems for effect on taste-and-odor. Water Sci Technol. 2004;49:75-80.

[20] Lehtola MJ, Miettinen IT, Keina“nen MM, Kekki T, Laine O, Hirvonen A, et al. Water Res. 2004;38(17):3769-3779. DOI: 10.1016/j.watres.2004.06.024.

[21] Heim TH, Dietrich AM. Water Res. 2007;41:757-764. DOI: 10.1016/j.watres.2006.11.028.

[22] Skjevrak I, Due A, Gjerstad KO, Herikstad H. Water Res. 2003;37:1912-1920. DOI: 10.1016/S0043-1354(02)00576-6.

[23] Mikami N, Gomi H, Miyamoto J. Studies on degradation of 2,6-di-tert-butyl-4-methylphenol (BHT) in the environment. Part-I: degradation of ${ }^{14} \mathrm{C}-\mathrm{BHT}$ in soil. Chemosphere. 1979;5:305-310.

[24] Matsuo M, Mihara K, Okuno M, Ohkawa H, Miyamoto J. Food Chem Toxicol. 1984;22:345-354. DOI: 10.1016/0278-6915(84)90362-4.

[25] Fernandez-Alvarez M, Lores M, Jover E, Garcia-Jares C, Bayona JM, Llommpart M. J Chromatogr A. 2009;1216:8969-8978. DOI: 10.1016/j.chroma.2009.10.047.

[26] Ortiz-Vazquez H, Shin J, Soto-Valdez H, Auras R. Polym Test. 2011;30:463-471. DOI: 10.1016/j.polymertesting.2011.03.006.

[27] Fries E, Puttmann W. Sci Total Environ. 2004;319:269-282. DOI: 10.1016/S0048-9697(03)00447-9.

[28] BHT: The versatile antioxidant for today and tomorrow. Sher-win-Williams Company, Bull. Ox. 12, Cleveland: 1992.

[29] Rossman LA, Boulos PF, Altman T. J Water Res Plan Man. 1993;119(5):505-517. DOI: 10.1061/(ASCE)0733-9496(1993)119:5(505).

[30] Kowalska B, Musz A, Kowalski D. Water quality modeling in a part of a real distribution system. Case studies. Polish J Environ Stud. 2009;18(3A):169-175.

[31] Zimoch I. Modelowanie zmian zawartości trójhalometanów w wodzie wodociągowej. Ochr Środow. 2011;33(3):35-42.

[32] Farmer R, Pike R, Cheng G. Comput Chem Eng. 2005;29:2386-2403. DOI: 10.1016/j.compchemeng.2005.05.022.

[33] Widomski M, Kowalska B, Musz A. Ecol Chem Eng A. 2013;1(20):99-108. DOI: 10.2428/ecea.2013.20(01)011.

[34] Farmer R, Pike R, Cheng G. Comput Chem Eng. 2005;29:2386-2403. DOI:10.1016/j.compchemeng.2005.05.022.

[35] Dufresne M, Vazquez J, Terfous A, Ghenaim A, Poulet JB. Comput Fluids. 2009;38:1042-1049. DOI: 10.1016/j.compfluid.2008.01.011.

[36] Rauen WB, Lin B, Falconer RA, Teixeira EC. Chem Eng J. 2008;137:550-560. DOI: 10.1016/j.cej.2007.05.011.

[37] Ho J. Water Sci Technol. 2011;63(12):3020-3026. DOI: 10.2166/wst.2011.638.

[38] LeMoullec Y, Gentric C, Potier O, Leclerc JP. Chem Eng Sci. 2010;65:343-350. DOI: 10.1016/j.ces.2009.06.035.

[39] Chen J, Deng B, Kim ChN. Chem Eng Sci. 2011;66:4983-4990. DOI: 10.1016/j.ces.2011.06.043.

[40] Ahmad AL, Lau KK, Bakar A, Shukor A. Comput Chem Eng. 2005;29:2087-2095. DOI: 10.1016/j.compchemeng.2005.06.001.

[41] Norton T, Sun DW. Trends Food Sci Tech. 2006;17:600-620. DOI: 10.1016/j.tifs.2006.05.004.

[42] Mohammadi H, Bahramian F. Cardiovasc Eng. 2009;9(3):83-91. DOI: 10.1007/s10558-009-9078-z. 
[43] Ma L, Ashworth PJ, Best JL, Elliott L, Ingham DB, Whitcombe LJ. Geomorphology. 2002;44:375-391. DOI: $10.1016 / \mathrm{S} 0169-555 \mathrm{X}(01) 00184-2$.

[44] Liu SX, Peng M. Comput Electron Agr. 2005;49:309-314. DOI: 10.1016/j.compag.2005.05.003.

[45] Janowska J, Widomski MK, Iwanek M, Musz A. Environ Eng IV. 2013:41-49. DOI: 10.1201/b14894-8.

[46] Widomski MK, Kowalska B, Kowalski D. Badania modelowe rozprzestrzeniania się butylohydroksytoulenu (BHT) migrującego z rury polietylenowej (PE-HD) do wody. Ochr Środow. 2012;3(34):33-37.

[47] Craft TJ, Gant SE, Iacovides H, Launder BE. Numer Heat Tr, Part B. 2004;45:301-318. DOI: 10.1080/10407790490277931.

[48] Choi YD, Iacovides H, Launder BE. J Fluid Eng. 1989;111:59-68. DOI: 10.1115/1.3243600.

[49] Wesseling P. Principles of Computational Fluid Mechanics. Springer Series in Computational Mathematics 2000;29:167-188.

[50] Ansys Fluent CFD Manual, 2009.

[51] Widomski M, Kowalska B, Kowalski D, Czerwiński J, Kwietniewski M. Urban Water. 2012:49-62. DOI: 10.2495/UW120051.

[52] Launder BE, Sharma BI. Letters in Heat and Mass Transfer. 1974;1(2):131-137. DOI: 10.1016/0094-4548(74)90150-7.

[53] Puzyrewski R, Sawicki JM. Podstawy mechaniki płynów i hydrauliki. Wyd. III. Warszawa: Wyd Nauk PWN; 2000.

[54] Bardina JE, Huang PG, Coakley TJ. Turbulence Modeling Validation, Testing, and Development, Moffett Field, California: NASA Technical Memorandum 1997.

[55] Dong W, Gijsman P. Polym Degrad Stabil. 2010;95:955-959. DOI: 10.1016/j.polymdegradstab.2010.03.020.

[56] Saulov DN, Watanabe S, Yin J, Klimenko DA, Hooman K, Feng B, et al. Energies. 2014;7:1899-1916. DOI: 10.3390/en7041899.

[57] Telenta M, Duhovnik J, Kosel F, Šajn V. J Wind Eng Ind Aerod. 2014;124:99-108. DOI: 10.1016/j.jweia.2013.11.010.

\title{
ZASTOSOWANIE MODELOWANIA NUMERYCZNEGO W ILOŚCIOWEJ OCENIE TRANSPORTU BHT W PRZEWODACH PE-HD
}

${ }^{1}$ Wydział Inżynierii Środowiska, Politechnika Lubelska

\begin{abstract}
Abstrakt: Przewody wodociągowe wykonane z PE-HD narażone są na wpływ niekorzystnych warunków zewnętrznych zarówno na etapie produkcji, jak i ich późniejszego wykorzystania w budownictwie. Związki organiczne migrujące do wody mogą powodować zmianę jej właściwości organoleptycznych, pogorszenie smaku i zapachu. W wyniku degradacji materiału przewodów do wody wymywany jest m.in. powszechnie stosowany przeciwutleniacz BHT lub produkty jego degradacji. W pracy przedstawiono wyniki badań laboratoryjnych zmian stężenia BHT w wodzie krążącej w przewodach z PE-HD oraz badań numerycznych. Obliczenia numeryczne wykonano z wykorzystaniem komercyjnego programu Fluent, Ansys Inc., bazującego na obliczeniowej dynamice płynów (CFD). Analiza próbek wody potwierdziła migrację przeciwutleniacza z materiału rury do wody. Wyniki analiz numerycznych dały dobrą zgodność z wartościami pomierzonymi.
\end{abstract}

Słowa kluczowe: migracja przeciwutleniaczy, BHT, rury PE-HD, modelowanie numeryczne 